\title{
Mycolic acid composition of Corynebacterium glutamicum and its cell surface mutants: effects of growth with glycine and isonicotinic acid hydrazide
}

\author{
Ki-Hyo Jang, ${ }^{1}$ David Pierotti, ${ }^{2}$ Gregory W. Kemp, ${ }^{3}$ Geoffrey R. Best ${ }^{2}$ \\ and Margaret L. Britz'
}

Author for correspondence: Margaret L. Britz. Tel: +61 39216 8136. Fax: +61392168135.

e-mail : Margaret=Britz@vut.edu.au

1 Centre for Bioprocessing and Food Technology,

Werribee Campus, Victoria University of Technology, PO Box 14428, MCMC, Melbourne 8001, Australia

2 Department of Applied Biology and

Biotechnology, Royal Melbourne Institute of Technology, PO Box

2476V, Melbourne,

Victoria 3001, Australia

3 CSIRO Division of Biomolecular Engineering, Parkville, Victoria 3052, Australia
Auxotrophic mutants of Corynebacterium glutamicum strain ATCC 13059 (parent of AS019, a rifampicin-resistant variant), which were morphologically distinct from the parent and formed protoplasts more readily, had been isolated previously. Mutants MLB130-133 and MLB194 were more sensitive to growth inhibition by isonicotinic acid hydrazide (INH) and glycine, which caused branching and budding. Fatty acid and mycolic acid (MA) profiles were determined after growth in LBG (Luria broth plus glucose), LBG-glycine (LBG-G) and LBG-INH (LBG-I). The fatty acid profiles of all strains were similar, except that mutant MLB133 showed some increase in stearic acid $\left(C_{18: 0}\right)$, normally a minor component, late in the growth cycle and oleic acid proportionately decreased. All strains had five major types of MAs $\left(C_{32: 0,} C_{34: 0,} C_{34: 1,} C_{36: 1,}\right.$ $C_{36: 2}$ ) but the relative proportion of each varied with the strain, age of culture and medium composition. Mutants MLB133 and MLB194 showed slightly higher levels of non-covalently bound MAs than the parent and normally showed a higher proportion of longer-chained, unsaturated MAs. The proportion of extracellular MAs increased with culture age for these mutants. Typically, by late stationary phase, mycolic acids in culture fluids increased to $6.5 \%$ of the total MAs for MLB194 and 7.9\% for MLB133 compared with 3.5\% for the parent strain grown in LBG. The main effect of glycine $(2 \%, w / v)$ addition was to increase the proportion of mycolic acids found in extracellular fluids (16.1\% for ASO19 and $31 \%$ for MLB133). The most significant effects of INH were seen when strains were cultured in LBG with $8 \mathrm{mg} \mathrm{INH} \mathrm{ml}^{-1}$. When harvested at late stationary phase, strains MLB133 and MLB194 had 18.8\% and $\mathbf{2 1 . 2} \%$ extracellular mycolic acids respectively, with a significant increase in the relative proportion of unsaturated mycolic acids. This effect was not as marked for AS019, which also showed a similar decrease in $C_{32: 0}$ relative to increases in the proportion of $C_{34: 1}$ and $C_{36: 2}$, plus a corresponding increase in the overall proportion of unsaturated mycolic acids and increased extracellular mycolates $(8.5 \%)$. These results suggest that the mutations in strains MLB133 and MLB194 are associated with synthesis of specific mycolic acids (e.g. $\left.C_{32: 0}\right)$ and attachment of mycolic acids to the cell surface, both of which are likely target sites for glycine and INH action for cell-surface modifications. In addition to previously reported targeting of the peptidoglycan cross-linking, these results show that glycine affects mycolic acid attachment to the cell surface of $\mathbf{C}$. glutamicum.

Keywords: Corynebacterium glutamicum, mycolic acids, fatty acids, isonicotinic acid hydrazide, glycine

Abbreviations: $C_{14: 0,}$ myristic acid; $C_{15: 0,}$ pentadecanoic acid; $C_{16: 0,}$ palmitic acid; $C_{15: 1,}$ palmitoleic acid; $C_{17: 0,}$ heptadecanoic acid; $C_{18: 0,}$ stearic acid; $C_{18: 10}$ oleic acid; FID, flame ionization detector; FAME, fatty acid methyl ester; INH, isonicotinic acid hydrazide; MAME, mycolic acid methyl ester; TMS, trimethylsilyl. 


\section{INTRODUCTION}

Non-pathogenic, saprophytic corynebacteria, including species such as Corynebacterium glutamicum, are widely used for industrial production of various amino acids and nucleotides. Over the last 10-15 years, considerable progress in developing recombinant DNA techniques in coryneform species has enabled the expression of a variety of recombinant genes, including expression and secretion of heterologous proteins by $C$. glutamicum and Brevibacterium lactofermentum (Smith et al., 1986; Liebl et al., 1992; Billman-Jacobe et al., 1995). Barriers to successful introduction of foreign genes into corynebacteria include the presence of restriction-modification systems (Katsumata et al., 1984; Schäfer et al., 1994; Tauch et al., 1994; Jang et al., 1996), which preclude survival of heterologously derived plasmid DNA and cause low transformation efficiency (Serwold-Davis et al., 1987; Haynes \& Britz, 1990), and the physical barrier of a complex cell-wall structure (Haynes \& Britz, 1990). The saprophytic corynebacteria and Brevibacterium species are taxonomically related to Mycobacterium, Rbodococcus and Nocardia, which are distinguished by the unique presence of mycolic acids in their cell walls, which otherwise contain peptidoglycan and arabinogalactan (Barksdale \& Kim, 1977; Collins et al., 1982a; Tomiyasu, 1982; Chevalier et al., 1988). Indeed, mycolic acids are a major component of the cell wall structure of this group of bacteria where, for instance, up to $60 \%$ by weight of the mycobacterial cell wall is composed of mycolic acids (Jarlier \& Nikaido, 1994). Mycolic acids have a structural role which gives rise to the resistance of cells to harsh environments and causes the acid-fastness of mycobacteria; they probably play an important role in the restricted permeability of these microbes to water-soluble molecules (Jarlier \& Nikaido, 1990).

The mycolic acid composition of C. glutamicum NCIB 10025 (Collins et al., 1982a) and the pathogenic coryneform Corynebacterium diphtheriae (Corina \& Sesardic, $1980)$ has been reported. For the former, Collins $e t$ al. (1982a, b) described the fatty acid and the mycolic acid components of stationary-phase cells, providing no information on whether the cell growth phase affected the type or proportion of mycolic acids present. Since cell growth phase was one of the key parameters determining transformation efficiency in C. glutamicum (Haynes \& Britz, 1990), more intensive studies on mycolic acid composition and modulation of this were warranted. Furthermore, it had been noted that growth of this species in the presence of glycine improved transformation efficiency (Yoshihama et al., 1985; Haynes \& Britz, 1990). Hammes et al. (1973) had reported that the structure of peptidoglycan in the Gram-positive cell wall was altered following growth in medium containing glycine, where these authors suggested that glycine substituted for alanine in the peptidoglycan, impairing cross-linking and weakening the peptidoglycan structure. Growth in the presence of glycine has been used as a preliminary step to protoplasting Streptomyces species (Hopwood et al., 1977) and this approach was applied successfully in $C$. glutamicum, since cells that are more osmotically sensitive are obtained following growth in glycine and lysozyme treatment (Best \& Britz, 1986; Wolf et al., 1989). Haynes \& Britz (1990) evaluated the effect of prior growth in the presence of isonicotinic acid hydrazide (INH) on electrotransformation frequency of C. glutamicum. INH was used because of its historical application in treating Mycobacterium infections, notably tuberculosis, where it is believed to act on mycolic acid biosynthesis (Winder \& Collins, 1970; Tomiyasu \& Yano, 1984; Banerjee et al., 1994; Quémard et al., 1995). Growth of C. glutamicum in the presence of $2.5 \%$ $(\mathrm{w} / \mathrm{v})$ glycine increased plasmid transformation efficiencies 10 -fold and addition of INH $\left(4 \mathrm{mg} \mathrm{m}^{-1}\right)$ produced a further 10 -fold increase relative to cells grown without these chemicals (Haynes \& Britz, 1990). Although data on structural changes in the cell surface were not provided, it was hypothesized that growth in the presence of glycine and INH modified peptidoglycan or mycolic acid structures to improve DNA entry into osmotically sensitive cells during electroporation. Furthermore, mutants which were originally isolated as auxotrophic for various branched-chain amino acids protoplasted more readily than their parent (Best \& Britz, 1986) and these mutants showed higher protoplast transformation frequencies following growth in glycine and INH (unpublished observation). Preliminary observations indicated that these mutants were more susceptible to inhibition by glycine and INH (noting that $C$. glutamicum is relatively insensitive to INH when compared to Mycobacterium species), suggesting that these mutants had altered cell-surface properties. To gain some insight into the nature of these mutations and the mechanism of action of glycine and INH, we analysed the fatty acid and mycolic acid composition of $C$. glutamicum strain ATCC 13059 and selected mutants which had been previously shown to protoplast more readily, with specific reference to the lipid composition following growth in glycine and $\mathrm{INH}$.

\section{METHODS}

Strains, media and growth conditions. C. glutamicum strains and their sources are shown in Table 1. Except for AS019, a spontaneous rifampicin-resistant strain of ATCC 13059, all of the auxotrophic mutants were derived from ATCC 13059 by long-term exposure to ethyl methanesulphonate (Best \& Britz, 1986). The basal medium used for routine bacterial growth was Luria broth (LB), which contained $10 \mathrm{~g}$ tryptone, $5 \mathrm{~g}$ yeast extract and $5 \mathrm{~g}$ sodium chloride per litre, $\mathrm{pH} 7 \cdot 2$. After sterilization, the medium was supplemented with $0.5 \%(\mathrm{w} / \mathrm{v})$ glucose from a $20 \%(\mathrm{w} / \mathrm{v})$ stock solution (LBG) when required. For plates, $\mathrm{LB}$ was solidified with $15 \mathrm{~g} \operatorname{agar~}^{-1}$ (LA). Liquid cultures were grown at $30^{\circ} \mathrm{C}$ and 200 r.p.m. in an orbital incubator, with growth monitored spectrophotometrically (Ultraspec, LKB) at $600 \mathrm{~nm}$.

Growth in media supplemented with glycine and INH. To test the effects of glycine and INH on growth rates, strains were inoculated into $100 \mathrm{ml} \mathrm{LBG}$ in $250 \mathrm{ml}$ flasks supplemented with glycine $(0-10 \%, w / v)$ or INH $\left(0-10 \mathrm{mg} \mathrm{ml}^{-1}\right)$ from sterile stock solutions $(20 \%, \mathrm{w} / \mathrm{v}$, glycine and $100 \mathrm{mg}$ INH 
Table 1. Auxotrophic requirements and protoplasting efficiency of $C$. glutamicum strains used

\begin{tabular}{|c|c|c|c|}
\hline Strain & Characteristics* & $\begin{array}{c}\text { Protoplasting } \\
\text { efficiency } \\
(\%) \dagger\end{array}$ & Reference/source \\
\hline ATCC 13059 & Wild-type & $12 \cdot 0$ & Yoshihama et al. (1985) \\
\hline AS019 & $\operatorname{Rif}^{r}$ & $12 \cdot 5$ & Yoshihama et al. (1985) \\
\hline MLB50 & Ileu- & 71 & Best \& Britz (1986) \\
\hline MLB112 & Ileu $^{-} \mathrm{His}^{-}$ & 84 & Best \& Britz (1986) \\
\hline MLB133 & 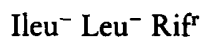 & $>99$ & Best \& Britz (1986) \\
\hline MLB194 & Ileu $^{-} \mathrm{His}^{-} \mathrm{Rif}^{\mathrm{r}}$ & 99 & Best \& Britz (1986) \\
\hline
\end{tabular}

* Ileu-, auxotrophic for isoleucine; $\mathrm{His}^{-}$, auxotrophic for histidine; Leu-, auxotrophic for leucine; Rif ${ }^{r}$, rifampicin resistant.

†Data from Best \& Britz (1986).

$\left.\mathrm{ml}^{-1}\right)$, with a starting $\mathrm{OD}_{600}$ of $0 \cdot 1-0 \cdot 2$. Samples $(1 \mathrm{ml})$ were removed hourly for measurement of $\mathrm{OD}_{600}$ and specific growth rates $\left(\mu, \mathrm{h}^{-1}\right)$ calculated.

Scanning electron microscopy. Cells were collected from midexponential-phase cultures in LBG and LBG-glycine $(2 \%$, $\mathrm{w} / \mathrm{v}$ ), washed in $4 \%$ sucrose to provide osmotic protection then fixed to aluminium foil by treatment with $1 \%(v / v)$ glutaraldehyde in $0.1 \mathrm{M}$ phosphate buffer, $\mathrm{pH} 7 \cdot 2$. Fixed cells were washed with $4 \%$ sucrose then mounted onto specimen holders and coated with gold. Multiple fields were examined using several magnifications and representative cells were photographed.

Growth and preparation of cells for GC-MS analysis. For analysis of mycolic acids and fatty acids, cultures were performed in several configurations depending on the size of samples required, including shake-flasks and fermenters. To compare mycolic acid composition for whole and defatted cells, cells were harvested during late-exponential-phase growth from $75 \mathrm{ml} \mathrm{LBG}$ cultures in $500 \mathrm{ml}$ flasks. To determine the effect of growth in the presence of glycine or INH on mycolic acid composition, cells were grown in $30 \mathrm{ml}$ of the following medium in $100 \mathrm{ml}$ flasks: LBG, LBG containing $2 \%(\mathrm{w} / \mathrm{v})$ glycine (LBG-G) or LBG containing $4 \mathrm{mg} \mathrm{INH} \mathrm{ml}^{-1}$ (LBG-I), harvesting at early stationary phase. To determine the mycolic and fatty acid composition at various growth phases, a 10-litre fermenter (LH 2000 series) containing 7 litres of LBG was inoculated from a $500 \mathrm{ml} \mathrm{LBG}$ starter culture to give a starting $\mathrm{OD}_{600}$ of $0 \cdot 3$. The air flow $\left(2.51 \mathrm{~min}^{-1}\right)$ and agitation (250 r.p.m.) were controlled during the fermentation to maintain a dissolved oxygen concentration of no less than $20 \%$ saturation. Samples $(500 \mathrm{ml})$ were taken at various stages throughout the growth cycle. Cells were routinely collected by centrifugation, washed twice in distilled water and then lyophilized. Culture supernatants were filtered $(0.22 \mu \mathrm{m}$, Millipore $)$ and stored at $-20^{\circ} \mathrm{C}$ before either freezedrying or solvent extraction prior to derivatization and analysis.

Isolation of fatty acid and mycolic acid from whole cells and culture fluids. Approximately $50 \mathrm{mg}$ of freeze-dried cells was subjected to acid methanolysis (methanol/toluene $/ \mathrm{H}_{2} \mathrm{SO}_{4}$, $30: 15: 1$, by vol., $3 \mathrm{ml}$ ) in sealed tubes for $16 \mathrm{~h}$ at $80^{\circ} \mathrm{C}$ as described by Minnikin et al. (1980). The liberated mycolic acid methyl esters (MAMEs) and fatty acid methyl esters (FAMEs) were extracted using petroleum ether (b.p. $60-80^{\circ} \mathrm{C}, 3 \times 2$ $\mathrm{ml}$ ). The extracts were combined then concentrated by drying under $\mathrm{N}_{2}$ flow and redissolving in a minimum volume of petroleum ether. MAMEs and FAMEs were separated by TLC on aluminium-baked silica-gel (Merck) using petroleum ether/acetone $(95: 5, \mathrm{v} / \mathrm{v})$, detecting MAMEs and FAMEs by spraying with a $10 \%(\mathrm{w} / \mathrm{v})$ ethanolic solution of molybdophosphoric acid followed by heating at $120^{\circ} \mathrm{C}$ for $15 \mathrm{~min}$. Areas corresponding to $R_{F}$ values of MAMEs and FAMEs were scraped from the sheet then extracted from the collected silica gel using diethyl ether $(3 \times 2 \mathrm{ml})$, which was then passed through a cotton wool plugged Pasteur pipette that had been previously rinsed with diethyl ether. The extracts were combined then dried under $\mathbf{N}_{2}$ flow and the residue treated with $100 \mu l$ trimethylsilylimidazole (TRI-SIL $\mathrm{Z}$, Pierce) for $20 \mathrm{~min}$ at $60^{\circ} \mathrm{C}$ to form the trimethylsilyl (TMS) derivatives of the MAMEs. For some experiments quantifying total mycolic acids in cells and culture fluids, the TLC step was omitted; after acid methanolysis of the dried cells and petroleum ether extraction, samples were dried under $\mathrm{N}_{2}$ flow, silylated and analysed by GC.

To quantify mycolic acids in culture supernatant samples from fermenter studies (Table 5), stored samples were lyophilized in $100 \mathrm{ml}$ batches and the combined residues derivatized by acid methanolysis, extracted using petroleum ether then dried under $\mathrm{N}_{2}$ as above. After dissolving in petroleum ether, MAMEs were separated using TLC then silylated. Alternatively, mycolic acids were extracted from culture fluids as described by Bligh \& Dyer (1959) (for data reported in Tables 6 and 7). The filtered culture fluids, $30 \mathrm{ml}$ or $100 \mathrm{ml}$, were mixed at $30^{\circ} \mathrm{C}$ for $1 \mathrm{~h}, 100 \mathrm{r}$.p.m., with 2.5 vols chloroform/methanol $(1: 2, \mathrm{v} / \mathrm{v})$ then held stationary for $4 \mathrm{~h}$. Subsequently, 1 vol. chloroform and 1 vol. deionized water were added, incubated for $1 \mathrm{~h}$ at $100 \mathrm{r.p.m}$, then the mixture was transferred to a separating funnel to allow separation for $16 \mathrm{~h}$. After collecting the bottom layer, the extract was dried and derivatized by acid methanolysis; MAMEs were extracted into petroleum ether then concentrated under $\mathrm{N}_{2}$ before trimethylsilylation as above.

Analysis of covalently bound mycolic acids. Covalently bound mycolic acids were extracted from freeze-dried cells using the method of Bligh \& Dyer (1959) modified as described by Minnikin et al. (1977). Cells (50 mg) were defatted by incubating in $6.75 \mathrm{ml}$ chloroform/methanol $/ 0.3 \%$ aqueous sodium chloride (30:100:40, by vol.) at room temperature with occasional mixing for $4 \mathrm{~h}$. Defatted cells were collected by centrifugation, washed with methanol and dried under $\mathrm{N}_{2}$ 
flow; then the covalently bound mycolic acids were subjected to acid methanolysis, extraction and purification of MAMEs by TLC as described above. Finally, samples were silylated.

GC-MS. Purified FAMEs were fractionated by GC on a Shimadzu gas chromatograph (GC-9A) fitted with an $8 \mathrm{~m}$ polar BP-20 $(0.25 \mu \mathrm{m}$ film thickness, bound fused silica, SGE, Scientific Pty) and using helium $\left(0.6 \mathrm{ml} \mathrm{min}^{-1}\right)$ as the carrier gas. The injection port and the flame ionization detector (FID) were kept at $220^{\circ} \mathrm{C}$. The oven temperature was initially $100^{\circ} \mathrm{C}$ for $1 \mathrm{~min}$ and then programmed to increase by $5^{\circ} \mathrm{C} \mathrm{min}^{-1}$ to $195^{\circ} \mathrm{C}$. The identity of individual FAMEs was established by comparison of the retention time with those of standard FAMEs containing known amount of saturated and unsaturated FAMEs $\left(\mathrm{C}_{12}-\mathrm{C}_{20}\right.$, Sigma $)$. The peak areas were measured with a Shimadzu C-R3A Chromatopac integrator and the relative proportions of fatty acids were calculated from the peak areas.

TMS ethers of MAMEs were analysed by GC on a Hewlett Packard 5890 gas chromatograph equipped with an FID, using a $12 \mathrm{~m}$ non-polar BP-1 capillary column $(0.22 \mathrm{~mm}$ i.d., $0.33 \mathrm{~mm}$ o.d., coated with BP-1, SGE, Scientific Pty). One microlitre of the derivatized extract was injected onto the column. The oven temperature was programmed at $260^{\circ} \mathrm{C}$ for $1 \mathrm{~min}$, then increased by $3^{\circ} \mathrm{C} \mathrm{min}^{-1}$ to $300^{\circ} \mathrm{C}$. The injector temperature was $300^{\circ} \mathrm{C}$, the flow rate of the carrier gas (helium) was $0.6 \mathrm{ml} \mathrm{min}^{-1}$ and the split ratio was $40: 1$. The relative proportions of TMS ethers of MAMEs were determined from peak areas measured using a Hewlett Packard $3393 \mathrm{~A}$ integrator.

When determining the effect of growth in the presence of glycine and $\mathrm{INH}$ on mycolic acid composition, $100 \mu \mathrm{l}$ lignoceric acid methyl ester $\left(\mathrm{C}_{25} \mathrm{H}_{50} \mathrm{O}_{2}\right.$, Sigma $)$ was added as an internal standard to each sample prior to extraction and all analyses were standardized using the area obtained following extraction and derivatization of this $C_{25}$ internal standard. The TMS ethers were analysed by GC using a Varian Star $3400 \mathrm{CX}$ gas chromatograph fitted with an FID. One microlitre of the solution was injected onto a $25 \mathrm{~m}$ non-polar BPX5 column $(0.22 \mathrm{~mm}$ i.d., $0.33 \mathrm{~mm}$ o.d., fused silica, SGE, Scientific Pty) with the split ratio set at $85: 1$. The oven temperature program was $260^{\circ} \mathrm{C}$ for $1 \mathrm{~min}$, then increasing by $4^{\circ} \mathrm{C} \mathrm{min}$ to $300^{\circ} \mathrm{C}$, then increasing to $320^{\circ} \mathrm{C}$ at $1^{\circ} \mathrm{C} \mathrm{min}{ }^{-1}$. Finally, the column temperature was held at $320^{\circ} \mathrm{C}$ for $3 \mathrm{~min}$. The injection temperature and the detector temperature were $300{ }^{\circ} \mathrm{C}$. $\mathrm{N}_{2}$ was used as the carrier gas $\left(0.6 \mathrm{ml} \mathrm{min}^{-1}\right)$.

The identity of the fractionated mycolic acid TMS ethers obtained by GC was determined by GC-MS (Carlo Erba/ Kratos High Resolution GC/MS or a Varian Saturn II GC/MS) equipped with a direct insertion probe. For GC-MS analysis, the column (12 m non-polar BP-1 capillary column) was directly coupled to the ion source, which was held at $300^{\circ} \mathrm{C}$, and helium $\left(1.0 \mathrm{ml} \mathrm{min} \mathrm{m}^{-1}\right)$ was used as carrier gas. The oven temperature was programmed at $260^{\circ} \mathrm{C}$ for $1 \mathrm{~min}$, then increasing by $10^{\circ} \mathrm{C} \mathrm{min}^{-1}$ to $340^{\circ} \mathrm{C}$. Electron impact ionization was used and the ionization potential was $70 \mathrm{eV}$.

Reproducibility of analyses was verified as follows. Five injections were carried out using various concentrations of mycolic acids; there was a linear relationship between the peak area detected corresponding to each mycolic acid and the amount of mycolic acids applied, with less than $2 \%$ variation in detected amounts between injections. For analyses of the composition of both fatty acids and mycolic acids following different growth conditions or for different strains, replicates were performed within each experiment and several independent experiments were performed for each set of conditions. Results reported for each type of experiment were consistent between replicates within any one experiment but some quantitative variations in the mycolic acid composition occurred between separate runs, which has also been reported by other workers (Herrera-Alcaraz et al., 1993). The standard deviations seen for relative proportions of mycolic acids detected ranged from $\pm 0.5 \%$ for minor mycolic acids $\left(\mathrm{C}_{36: 1}\right)$ to a maximum of $\pm 4.6 \%$ for major mycolic acids $\left(C_{32: 0}\right)$ when averaged across four replicate experiments. The trends seen for the relative proportions of mycolic acids present were identical in every analysis for a particular strain or set of experimental conditions; hence representative figures are shown in Results rather than a mean of percentage composition between experiments, unless otherwise stated.

\section{RESULTS}

\section{Influence of glycine and INH on cell growth}

Cell growth with different concentrations of glycine and INH was compared for C. glutamicum AS019 and the readily protoplasted mutants to identify any differences
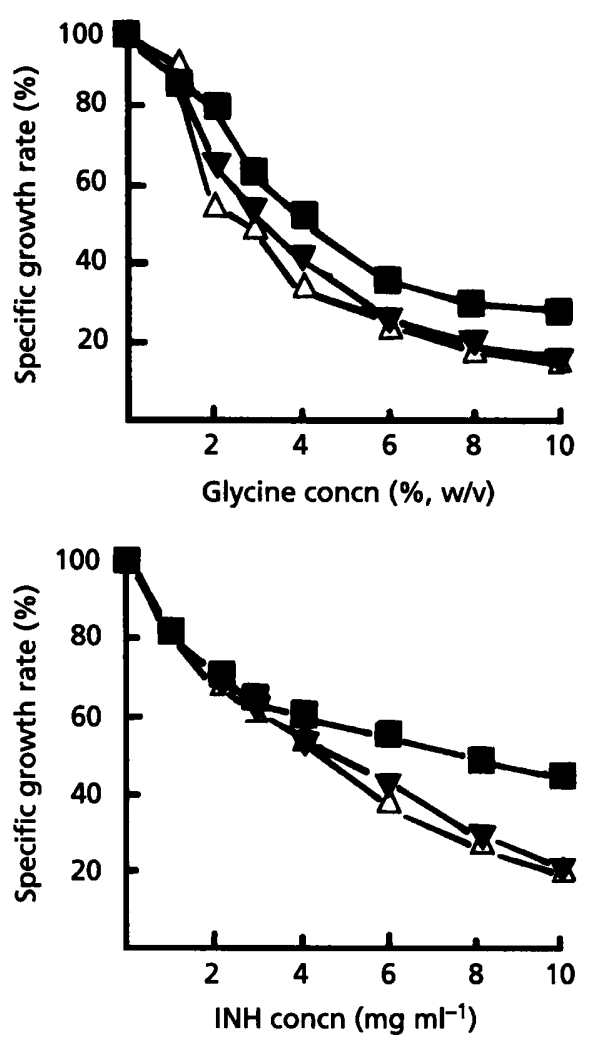

Fig. 1. Comparison of specific growth rates of $C$. glutamicum strains in the presence or absence of glycine or INH: AS019 ( $\square$ ), MLB133 $(\nabla)$ and MLB194 $(\triangle)$. Cells were grown in $100 \mathrm{ml}$ LBG in $250 \mathrm{ml}$ flasks with or without glycine $(0-10 \%, w / v)$ or INH $\left(0-10 \mathrm{mg} \mathrm{ml}^{-1}\right)$, at $30^{\circ} \mathrm{C}$ and 200 r.p.m. Specific growth rates are expressed as the percentage of the growth rate in LBG. Each value is the mean percentage of the specific growth rate of two independent experiments. 

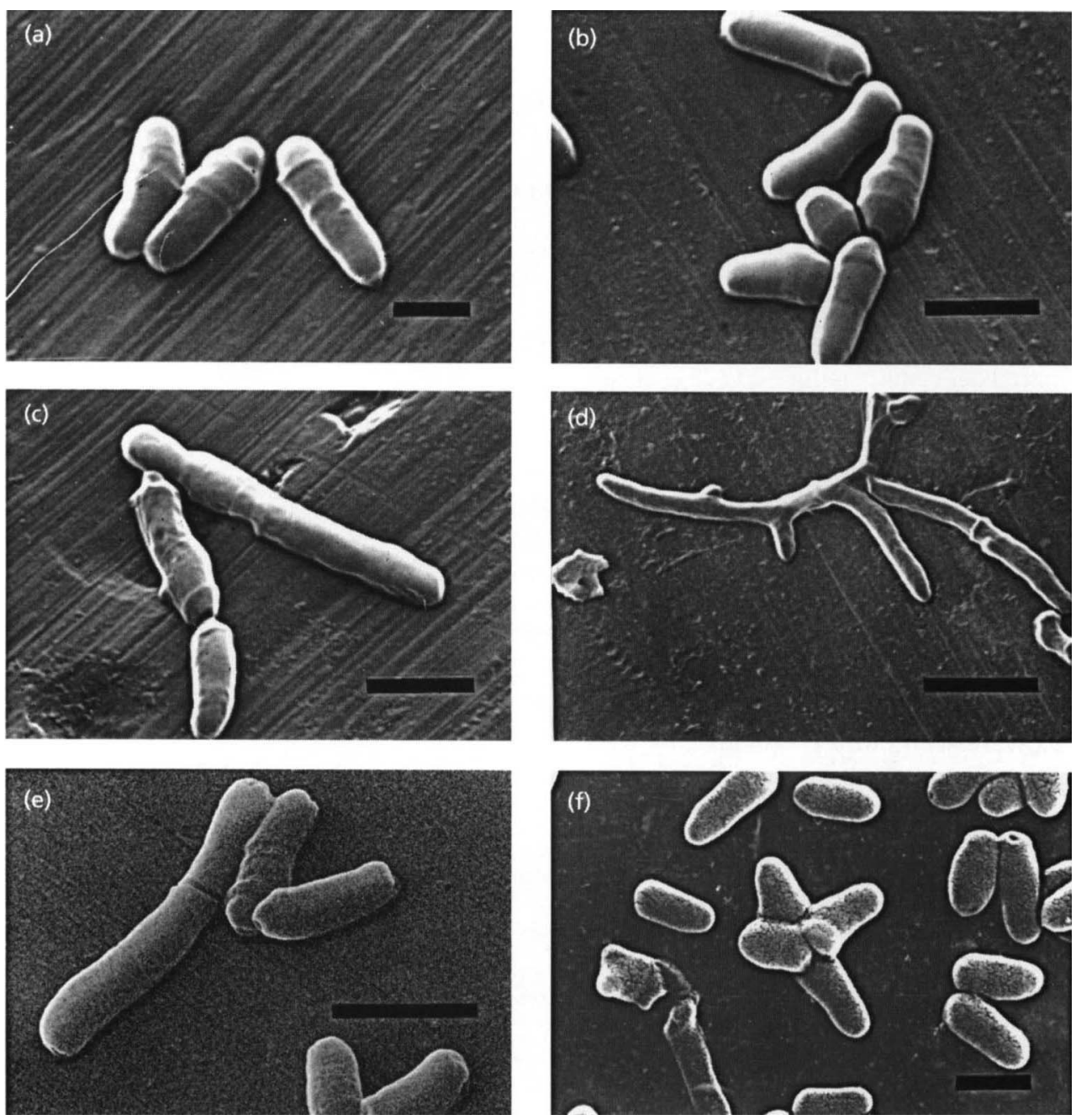

Fig. 2. Scanning electron microscopy of $C$. glutamicum strains following growth in the presence or absence of glycine. (a, c, e) Cells grown on LB: ATCC 13059 (a), MLB50 (c), MLB112 (e). (b, d, f) Cells grown on LB containing $2 \%$ (w/v) glycine: ATCC 13059 (b), MLB50 (d), MLB112 (f). Bars: (a), $1 \mu \mathrm{m}$; (b, c, e, f), $2 \mu \mathrm{m}$; (d), $4 \mu \mathrm{m}$.

in sensitivity to these additives. The specific growth rates of all strains tested decreased as the concentration of glycine or INH in the growth medium increased (Fig. 1). Strain MLB133 grew much more slowly in LBG than the other two strains, with a long lag period (data not shown), so growth rates are expressed as percentages relative to controls in LBG to enable comparison between strains. The concentration of glycine which caused a $50 \%$ decrease in specific growth rate was $4 \%$ (w/v) for AS019 and 2-3\% for MLB133 and MLB194; higher concentrations of glycine significantly impaired growth of the mutants, further demonstrating the greater sensitivity of these strains to growth inhibition by glycine. These mutants were also more sensitive than the parent strain to inhibition by INH (Fig. 1). However, these and other strains of $C$. glutamicum were not inhibited by concentrations of INH $\left(0 \cdot 1 \mathrm{mg} \mathrm{m}^{-1}\right)$ known to completely inhibit growth of Mycobacterium,
Nocardia and Rbodococcus (Tomiyasu \& Yano, 1984), demonstrating that the saprophytic coryneforms are normally far less sensitive to INH than these genera.

\section{Morphology}

Fig. 2 shows scanning electron micrographs of several strains of C. glutamicum following growth in the presence or absence of $2 \%$ glycine. Strain ATCC 13059 grown in the absence of glycine showed the typical irregular rods of this species, with coccobacilli 1-2 $\mu \mathrm{m}$ in length. Characteristically, this strain forms parallel ridges around its circumference. However, growth in LGG-G caused some cell elongation and the rare appearance of X-and Y-shaped cells. Mutants derived from this strain, which were previously shown to protoplast more readily (Best \& Britz, 1986), normally produced elongated cells when grown in the absence of 
Table 2. Fatty acid composition of C. glutamicum after growth at $30^{\circ} \mathrm{C}$ on LBG

Samples $(500 \mathrm{ml})$ were removed at different phases of growth for 7 litre LBG fermentations. See Methods for further details of culture and extraction conditions. Values represent the proportion of each fatty acid as a percentage of the total in terms of peak area detected. FAMEs derived from TLC were analysed by GC. Abbreviations: EE, early exponential phase; ME, middle exponential phase; LE, late exponential phase; ES, early stationary phase; LS, late stationary phase. The numbers in parentheses represent the culture $\mathrm{OD}_{600}$ at which cells were harvested. The maximal $\mathrm{OD}_{600}$ for cultures was 4-5. LS samples were obtained $12 \mathrm{~h}$ after ES samples.

\begin{tabular}{|c|c|c|c|c|c|c|c|c|c|c|c|c|c|c|}
\hline \multirow{2}{*}{$\begin{array}{l}\text { Fatty } \\
\text { acid }\end{array}$} & \multicolumn{5}{|c|}{ ATCC 13059} & \multicolumn{4}{|c|}{ MLB133 } & \multicolumn{5}{|c|}{ MLB194 } \\
\hline & $\begin{array}{c}\mathrm{EE} \\
(\mathbf{0} \cdot 65)\end{array}$ & $\begin{array}{c}\text { ME } \\
(\mathbf{1} \cdot 35)\end{array}$ & $\begin{array}{c}\text { LE } \\
(2 \cdot 40)\end{array}$ & $\begin{array}{c}\text { ES } \\
(4 \cdot 10)\end{array}$ & LS & $\begin{array}{c}\text { ME } \\
(\mathbf{1} \cdot 20)\end{array}$ & $\begin{array}{c}\text { LE } \\
(2 \cdot 10)\end{array}$ & $\begin{array}{c}\text { ES } \\
(4 \cdot 15)\end{array}$ & LS & $\begin{array}{c}\text { EE } \\
(\mathbf{0 . 6 5})\end{array}$ & $\underset{(1 \cdot 35)}{\text { ME }}$ & $\begin{array}{c}\text { LE } \\
(\mathbf{2} \cdot 80)\end{array}$ & $\underset{(5.05)}{\text { ES }}$ & LS \\
\hline$C_{14: 0}$ & 0.5 & 0.5 & 0.5 & 1.0 & $1 \cdot 0$ & 0.5 & 0.5 & $1 \cdot 0$ & $1 \cdot 0$ & 0.5 & 0.5 & 0.5 & 0.5 & $1 \cdot 0$ \\
\hline$C_{15: 0}$ & 0.5 & 0.5 & 0.5 & 0.5 & 0.5 & 0.5 & 0.5 & 0.5 & 0.5 & $<0.5$ & 0.5 & 0.5 & 0.5 & 0.5 \\
\hline$C_{16: 0}$ & $43 \cdot 0$ & $43 \cdot 5$ & $44 \cdot 5$ & $44 \cdot 5$ & $45 \cdot 0$ & 46.5 & $47 \cdot 0$ & 46.5 & 50.5 & 50.5 & 46.5 & $44 \cdot 5$ & 48.0 & $50 \cdot 0$ \\
\hline$C_{17: 0}$ & 0.5 & 0.5 & 0.5 & 0.5 & 0.5 & 0.5 & 0.5 & 0.5 & 0.5 & $<0.5$ & 0.5 & $0 \cdot 5$ & 0.5 & $<0.5$ \\
\hline$C_{18: 0}$ & $1 \cdot 5$ & 1.5 & 1.0 & $1 \cdot 0$ & $1 \cdot 5$ & 1.5 & 1.5 & 2.5 & 6.0 & $1 \cdot 0$ & 0.5 & 0.5 & $<0.5$ & 0.5 \\
\hline$C_{18: 1}^{10.0}$ & $54 \cdot 0$ & 53.5 & $53 \cdot 0$ & $52 \cdot 5$ & $51 \cdot 5$ & 50.5 & $50 \cdot 0$ & $49 \cdot 0$ & $41 \cdot 5$ & $48 \cdot 0$ & $51 \cdot 5$ & $53 \cdot 5$ & $50 \cdot 5$ & $48 \cdot 0$ \\
\hline
\end{tabular}

glycine. When the mutants were grown in LBG-G, Xand $\mathrm{Y}$ - shaped cells were seen more frequently, as were branched rods, suggesting that cell division here occurs through budding, branch formation, then septation. Similar observation were also made for all the readily protoplasted mutants, including MLB130-133 and MLB194 (strains derived from MLB50 and MLB112). This considerable pleomorphism, which resembled branching and filament formation, presumably arose due to modification of cell wall structures or changes in septation.

\section{Fatty acid composition of C. glutamicum grown in LBG}

The composition of the fatty acids from cells grown in LBG was determined at different growth phases for parent and mutant strains of C. glutamicum (Table 2).TLC of the methyl esters of the fatty acids from $C$. glutamicum gave two major spots, one corresponding to non-polar FAMEs and the other corresponding to MAMEs (data not shown). Palmitic $\left(\mathrm{C}_{16: 0}\right)$ and oleic $\left(\mathrm{C}_{18: 1}\right)$ acids constituted $92-98 \%$ of the total fatty acids detected by GC from all of the strains and all the growth phases (Table 2 shows results for selected strains). Myristic acid $\left(\mathrm{C}_{14: 0}\right)$, pentadecanoic acid $\left(\mathrm{C}_{15: 0}\right)$, palmitoleic acid $\left(\mathrm{C}_{16: 1}\right)$, heptadecanoic acid $\left(\mathrm{C}_{17: 0}\right)$ and stearic acid $\left(\mathrm{C}_{18: 0}\right)$ were also detected as minor components. As growth progressed, strain ATCC 13059 showed a small decrease in $\mathrm{C}_{18: 1}(54.0 \%$ to $51.5 \%)$ with an accompanying small increase in $C_{16: 0}(43.0 \%$ to $45.0 \%)$. The most noticeable differences between the parent strain and MLB133 were an increase in the proportion of $\mathrm{C}_{18: 0}$ $(1.5$ to $6.0 \%)$ late in growth of the latter strain, which was not seen for the parent or MLB194, with a parallel decline in the proportion of $\mathrm{C}_{18: 1}(50.5$ to $41.5 \%)$ late in growth, which resulted in this strain having a lower proportion of unsaturated fatty acids. There was also a small increase in palmitic acid late in growth of MLB133. (a)

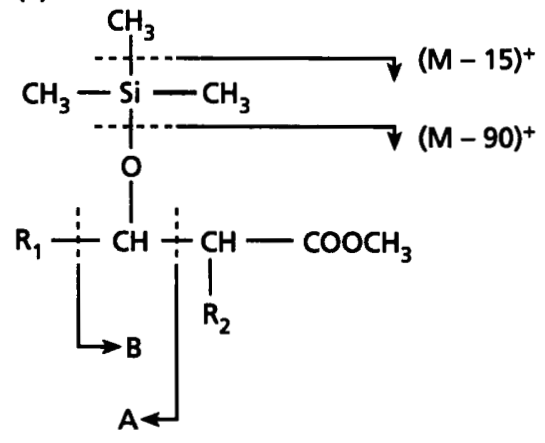

(a)

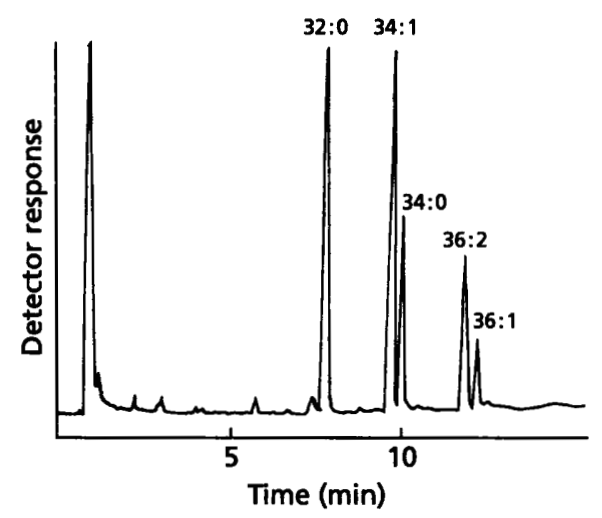

Fig. 3. (a) Fragmentation scheme for TMS ethers of MAMEs; (b) gas chromatogram of TMS derivatives of the MAMEs from $C$. glutamicum ASO19 on a non polar BP-1 bonded fused silica capillary column. GC conditions are described in Methods. On each peak, the first number indicates the number of carbon atoms and the second indicates the number of double bonds.

\section{Mycolic acid composition}

Two different approaches were taken for analysis of mycolic acids. The first involved pyrolytic cleavage of 
Table 3. Mycolic acid structures of $C$. glutamicum

Identical structures were found for all strains tested. See Fig. 3(a) for the overall structure of mycolic acids.

\begin{tabular}{|c|c|c|c|c|c|c|}
\hline \multicolumn{3}{|c|}{ Fragment ions $(m / z)$} & \multirow{2}{*}{$\begin{array}{l}\text { Formula of } \\
\text { acids }\end{array}$} & \multicolumn{2}{|c|}{ Side chain } & \multirow{2}{*}{$\begin{array}{l}\text { No. of double } \\
\text { bonds }\end{array}$} \\
\hline $\boldsymbol{M}$ & $M-15$ & $M-90$ & & $\mathbf{R} \mathbf{1}$ & $\mathbf{R 2}$ & \\
\hline 582 & 567 & 492 & $\mathrm{C}_{32} \mathrm{H}_{64} \mathrm{O}_{3}$ & $\mathrm{C}_{15} \mathrm{H}_{31}$ & $\mathrm{C}_{14} \mathrm{H}_{29}$ & 0 \\
\hline 608 & 593 & 518 & $\mathrm{C}_{34} \mathrm{H}_{66} \mathrm{O}_{3}$ & $\begin{array}{l}\mathrm{C}_{17} \mathrm{H}_{33} \\
\text { or } \mathrm{C}_{15} \mathrm{H}_{31}\end{array}$ & $\begin{array}{l}\mathrm{C}_{14} \mathrm{H}_{29} \\
\mathrm{C}_{18} \mathrm{H}_{31}\end{array}$ & 1 \\
\hline 610 & 595 & 520 & $\mathrm{C}_{34} \mathrm{H}_{68} \mathrm{O}_{3}$ & $\begin{array}{l}\mathrm{C}_{17} \mathrm{H}_{35} \\
\text { or } \mathrm{C}_{15} \mathrm{H}_{31}\end{array}$ & $\begin{array}{l}\mathrm{C}_{14} \mathrm{H}_{29} \\
\mathrm{C}_{16} \mathrm{H}_{33}\end{array}$ & 0 \\
\hline 634 & 619 & 544 & $\mathrm{C}_{36} \mathrm{H}_{68} \mathrm{O}_{3}$ & $\mathrm{C}_{17} \mathrm{H}_{33}$ & $\mathrm{C}_{16} \mathrm{H}_{31}$ & 2 \\
\hline 636 & 621 & 546 & $\mathrm{C}_{36} \mathrm{H}_{70} \mathrm{O}_{3}$ & $\mathrm{C}_{17} \mathrm{H}_{35}$ & $\mathrm{C}_{16} \mathrm{H}_{31}$ & 1 \\
\hline
\end{tabular}

MAMEs at high temperature, producing aldehydes and FAMEs. Using this protocol, six pyrolysis fragments were identified that corresponded to esters and aldehydes of $\mathrm{C}_{16: 0}, \mathrm{C}_{18: 0}$ and $\mathrm{C}_{18: 1}$ (data not shown), indicating that the possible parent mycolic acid species are: $\mathrm{C}_{32: 0}, \mathrm{C}_{34: 0}, \mathrm{C}_{34: 1}, \mathrm{C}_{36: 0}, \mathrm{C}_{36: 1}$, and $\mathrm{C}_{36: 2}$. The second approach involved derivatizing mycolic acids to MAMEs, purifying these by TLC then converting MAMEs into TMS ethers. Conversion of MAMEs to TMS ethers protects the molecules from pyrolysis and enables their analysis by conventional GC at high temperature. GC-MS analysis using this approach gives more diagnostic fragments when compared with mass spectra of non-silylated mycolic acid (Yano \& Saito, 1972; Athalye et al., 1984). Fig. 3 shows a typical GC profile for C. glutamicum strains and the fragmentation pattern of the TMS ethers of MAMEs, which were analysed by GC-MS to determine the overall structure of the mycolic acids. This was determined from peaks corresponding to the loss of a methyl group $[M-15]^{+}$and the loss of the trimethylsilyl group $[M-90]^{+}$(Yano \& Saito, 1972; Corina \& Sesardic, 1980). The R1 group and R2 group were determined from the peak caused by fragment $A$ and fragment $B$, respectively. A peak was commonly observed corresponding to B-29 (loss of ethyl group from fragment B) and this assisted in identifying the R2 side chain. Mass spectra of each peak from GC were analysed and are summarized in Table 3. Five major types of mycolic acid were fractionated and identified $\left(C_{32: 0}, C_{34: 0}, C_{34: 1}, C_{36: 1}, C_{36: 2}\right)$. These structures are in accord with the results obtained using pyrolytic cleavage.

\section{Comparison of mycolic acids present in whole and defatted cells}

Mycolic acids occur on the cell surface in two forms: covalently bound, which are not extractable by organic solvents and require acid or alkali treatment to cleave linkages during extraction and derivatization, and noncovalently bound lipids, which can be extracted from cells by solvents during 'defatting' (Tomiyasu \& Yano, 1984). Table 4 shows the analysis of mycolic acids of selected strains following acid methanolysis of whole cells with or without prior extraction of polar lipids to remove non-covalently bound mycolic acids. For all of the strains, the profile of mycolic acids was similar for both whole and defatted cells, indicating that the mutants did not have a differential change in the types of mycolic acids which were covalently bound. However, strains MLB133 and MLB194 displayed two distinct differences when compared with the parent strain ATCC 13059 and its rifampicin-resistant mutant, AS019: both strains had a lower proportion of bound mycolic acids (48.8 and $50.9 \%$, compared to $54.3 \%$ for AS019) and the proportion of unsaturated mycolic acids relative to total was significantly higher.

\section{Analysis of mycolic acid composition of whole cells and culture fluids at different growth phases}

The above results were obtained for cells harvested during late exponential phase and it could have been argued that differences in lipid profile were an artefact of growth phase. Strains ATCC 13059, MLB133 and MLB194 were therefore cultured in fermenters under controlled conditions and samples of cells plus culture fluids analysed for mycolic acids throughout the growth cycle (Table 5). For the parent strain ATCC 13059, a relatively small proportion of the total mycolic acids was found in the filtered culture fluids and the mycolic acid profiles for whole cells and culture fluids were similar, showing little change over the growth cycle. Extracellular mycolic acids increased slightly in late stationary phase cultures (final proportion, $3.5 \%$ ). In contrast, the mutant strains MLB133 and MLB194 showed an increase in the relative proportion of unsaturated mycolic acids as growth progressed, with an accompanying decline in the relative proportion of $\mathrm{C}_{32: 0}$ in particular. Both strains also showed a higher proportion of extracellular mycolic acids than the parent 
Table 4. Comparison of mycolic acid composition for whole and defatted cells of

\section{C. glutamicum strains}

Cells were grown in LBG and harvested during late-exponential phase. Non-covalently bound mycolic acids were extracted to yield defatted cells which contained the 'bound' mycolic acid. MAMEs from whole or defatted cells were analysed by GC following the TLC step, as described in Methods. See Methods for further details of culture and extraction conditions. Results are expressed as a percentage of the total mycolic acid content, in terms of peak area detected. Abbreviations: UM, unsaturated mycolic acids; TM, total mycolic acids; Wh. cell, mycolic acid from whole cells; Bound, covalently bound mycolic acid from defatted cells.

\begin{tabular}{|c|c|c|c|c|c|c|c|}
\hline \multirow[t]{2}{*}{ Mycolic acid } & \multirow{2}{*}{$\begin{array}{c}\text { ATCC } \\
13059 \\
\text { Wh. cell }\end{array}$} & \multicolumn{2}{|c|}{ AS019 } & \multicolumn{2}{|c|}{ MLB133 } & \multicolumn{2}{|c|}{ MLB194 } \\
\hline & & Wh. cell & Bound & Wh. cell & Bound & Wh. cell & Bound \\
\hline $\mathrm{C}_{32: 0}$ & $36 \cdot 4$ & $40 \cdot 3$ & $39 \cdot 5$ & $27 \cdot 6$ & $26 \cdot 7$ & $31 \cdot 4$ & $31 \cdot 0$ \\
\hline $\mathrm{C}_{34: 1}$ & $37 \cdot 2$ & $36 \cdot 6$ & $36 \cdot 8$ & $40 \cdot 7$ & $40 \cdot 7$ & $40 \cdot 0$ & $40 \cdot 5$ \\
\hline $\mathrm{C}_{34: 0}$ & $9 \cdot 6$ & $9 \cdot 4$ & $9 \cdot 3$ & $6 \cdot 1$ & $5 \cdot 2$ & $8 \cdot 7$ & $8 \cdot 9$ \\
\hline $\mathrm{C}_{36: 2}$ & $11 \cdot 7$ & $9 \cdot 3$ & $9 \cdot 7$ & $19 \cdot 9$ & $21 \cdot 7$ & $14 \cdot 3$ & $14 \cdot 2$ \\
\hline $\mathrm{C}_{36: 1}$ & $5 \cdot 1$ & $4 \cdot 4$ & $4 \cdot 7$ & $5 \cdot 7$ & $5 \cdot 7$ & $5 \cdot 6$ & $5 \cdot 4$ \\
\hline$\% \mathrm{UM}$ to $\mathrm{TM}^{*}$ & $54 \cdot 0$ & $50 \cdot 3$ & $51 \cdot 2$ & $66 \cdot 3$ & $68 \cdot 1$ & $59 \cdot 9$ & $60 \cdot 1$ \\
\hline $\begin{array}{l}\% \text { Bound } \\
\text { mycolic acids } \dagger\end{array}$ & & & $54 \cdot 3$ & & $48 \cdot 8$ & & $50 \cdot 9$ \\
\hline
\end{tabular}

* The ratio of UM to TM was determined by dividing the sum of the unsaturated mycolic acids values by the sum of the total mycolic acids.

†Percentage of mycolic acids in defatted cells relative to mycolic acids detected from whole cells.

Table 5. Comparison of mycolic acids found in culture fluids and whole cells of C. glutamicum strains

Samples $(500 \mathrm{ml})$ were removed at different phases of growth for 7 litre LBG fermentations. MAMEs were extracted from whole cells and culture fluids as described in Methods. The maximal $\mathrm{OD}_{600}$ for cultures was 4-5. After TLC separation, MAMEs were separated and analysed by GC. The results represent the proportion (\%) of each mycolic acid found in whole cells or culture fluids. See Tables 2 and 4 for abbreviations.

\begin{tabular}{|c|c|c|c|c|c|c|c|c|c|c|c|c|c|c|}
\hline \multirow[t]{2}{*}{ Mycolic acid } & \multicolumn{5}{|c|}{ ATCC 13059} & \multicolumn{4}{|c|}{ MLB133 } & \multicolumn{5}{|c|}{ MLB194 } \\
\hline & EE & ME & LE & ES & LS & ME & LE & ES & LS & EE & ME & LE & ES & LS \\
\hline \multicolumn{15}{|l|}{ From whole cells } \\
\hline $\mathrm{C}_{32: 0}$ & 34.9 & 33.9 & $34 \cdot 6$ & $35 \cdot 7$ & $37 \cdot 0$ & $26 \cdot 5$ & 26.9 & $21 \cdot 8$ & $19 \cdot 3$ & $48 \cdot 5$ & $43 \cdot 6$ & $36 \cdot 0$ & $37 \cdot 5$ & $39 \cdot 2$ \\
\hline $\mathrm{C}_{34: 1}$ & $36 \cdot 4$ & $37 \cdot 5$ & $37 \cdot 4$ & $36 \cdot 8$ & $35 \cdot 9$ & 33.6 & $37 \cdot 6$ & $36 \cdot 5$ & $34 \cdot 7$ & $28 \cdot 5$ & $32 \cdot 8$ & $36 \cdot 8$ & $37 \cdot 3$ & $38 \cdot 0$ \\
\hline $\mathrm{C}_{34: 0}$ & $10 \cdot 3$ & $10 \cdot 3$ & $10 \cdot 8$ & $10 \cdot 6$ & $10 \cdot 9$ & $14 \cdot 6$ & $12 \cdot 0$ & $12 \cdot 4$ & $12 \cdot 1$ & $14 \cdot 0$ & $11 \cdot 6$ & $11 \cdot 1$ & $10 \cdot 5$ & 8.9 \\
\hline $\mathrm{C}_{36: 2}$ & $12 \cdot 6$ & $12 \cdot 5$ & $11 \cdot 7$ & $11 \cdot 3$ & $10 \cdot 6$ & $14 \cdot 2$ & $14 \cdot 8$ & $18 \cdot 0$ & $23 \cdot 3$ & $5 \cdot 6$ & $7 \cdot 5$ & $10 \cdot 7$ & $9 \cdot 5$ & $9 \cdot 5$ \\
\hline $\mathrm{C}_{36: 1}$ & $5 \cdot 8$ & $5 \cdot 8$ & $5 \cdot 5$ & $5 \cdot 6$ & $5 \cdot 6$ & $11 \cdot 1$ & $8 \cdot 7$ & $11 \cdot 3$ & $10 \cdot 6$ & $3 \cdot 4$ & $4 \cdot 5$ & $5 \cdot 4$ & $5 \cdot 2$ & $4 \cdot 4$ \\
\hline$\%$ UM to $\mathrm{TM}^{*}$ & $54 \cdot 8$ & $55 \cdot 8$ & $54 \cdot 6$ & $53 \cdot 7$ & $52 \cdot 1$ & $58 \cdot 9$ & $61 \cdot 1$ & $65 \cdot 8$ & $68 \cdot 6$ & $37 \cdot 5$ & $44 \cdot 8$ & $52 \cdot 9$ & $52 \cdot 0$ & $51 \cdot 9$ \\
\hline \multicolumn{15}{|c|}{ From culture supernatant } \\
\hline $\mathrm{C}_{32: 0}$ & & & $35 \cdot 3$ & $36 \cdot 2$ & $36 \cdot 2$ & & $29 \cdot 5$ & $22 \cdot 2$ & $21 \cdot 2$ & & & $37 \cdot 3$ & $38 \cdot 2$ & $40 \cdot 6$ \\
\hline $\mathrm{C}_{34: 1}$ & & & $36 \cdot 7$ & $36 \cdot 4$ & $36 \cdot 4$ & & $33 \cdot 2$ & $35 \cdot 2$ & $35 \cdot 8$ & & & $36 \cdot 3$ & $37 \cdot 2$ & $37 \cdot 2$ \\
\hline $\mathrm{C}_{34: 0}$ & & & $10 \cdot 6$ & $10 \cdot 4$ & $10 \cdot 5$ & & $13 \cdot 8$ & $14 \cdot 9$ & $12 \cdot 4$ & & & $10 \cdot 8$ & $9 \cdot 8$ & $9 \cdot 7$ \\
\hline $\mathrm{C}_{36: 2}$ & & & $12 \cdot 3$ & $10 \cdot 9$ & $11 \cdot 3$ & & $12 \cdot 4$ & $15 \cdot 7$ & $21 \cdot 1$ & & & $10 \cdot 3$ & $9 \cdot 2$ & $8 \cdot 4$ \\
\hline $\mathrm{C}_{36: 1}$ & & & $5 \cdot 1$ & $6 \cdot 1$ & $5 \cdot 6$ & & $11 \cdot 1$ & $12 \cdot 0$ & $9 \cdot 5$ & & & $5 \cdot 3$ & $5 \cdot 6$ & $4 \cdot 1$ \\
\hline$\%$ UM to $\mathrm{TM}^{*}$ & & & $54 \cdot 1$ & $53 \cdot 4$ & $53 \cdot 3$ & & $56 \cdot 7$ & $62 \cdot 9$ & $66 \cdot 4$ & & & $51 \cdot 9$ & $52 \cdot 0$ & $49 \cdot 7$ \\
\hline Relative $\%$ of to & & & $1 \cdot 6$ & $1 \cdot 4$ & $3 \cdot 5$ & & 3.9 & $4 \cdot 5$ & $7 \cdot 9$ & & & $2 \cdot 0$ & $2 \cdot 4$ & $6 \cdot 5$ \\
\hline
\end{tabular}

*See Table 4.

†Percentage of mycolic acids found in culture fluids relative to total mycolic acids detected (whole cells plus culture fluids). 
Table 6. Mycolic acid composition of $C$. glutamicum strains grown in three different media

Cultures containing $30 \mathrm{ml}$ medium were grown in $250 \mathrm{ml}$ flasks at $30^{\circ} \mathrm{C}$, and harvested at the early stationary phase. Mycolic acids were extracted from dried whole cells and culture fluids as described in Methods, omitting TLC purification. After acid methanolysis of the dried cells, samples were extracted using petroleum ether, dried under $\mathrm{N}_{2}$, silylated to TMS ethers and then analysed by GC. Abbreviations: LBG-G, LBG supplemented with $2 \%(\mathrm{w} / \mathrm{v})$ glycine; LBG-I, LBG supplemented with $4 \mathrm{mg} \mathrm{INH} \mathrm{ml}^{-1}$. The results represent the proportion (\%) of each mycolic acid found in whole cells.

\begin{tabular}{|c|c|c|c|c|c|c|c|c|c|}
\hline \multirow[t]{2}{*}{ Mycolic acid } & \multicolumn{3}{|c|}{ AS019 } & \multicolumn{3}{|c|}{ MLB133 } & \multicolumn{3}{|c|}{ MLB194 } \\
\hline & LBG & LBG-G & LBG-I & LBG & LBG-G & LBG-I & LBG & LBG-G & LBG-I \\
\hline $\mathrm{C}_{32: 0}$ & $51 \cdot 0$ & $52 \cdot 0$ & $49 \cdot 2$ & $33 \cdot 7$ & $41 \cdot 3$ & $38 \cdot 0$ & $38 \cdot 7$ & $41 \cdot 2$ & $47 \cdot 0$ \\
\hline $\mathrm{C}_{34: 1}$ & $30 \cdot 1$ & $30 \cdot 2$ & $31 \cdot 5$ & $40 \cdot 3$ & $38 \cdot 1$ & $39 \cdot 0$ & $38 \cdot 2$ & $36 \cdot 7$ & $35 \cdot 2$ \\
\hline $\mathrm{C}_{34: 0}$ & $9 \cdot 4$ & $10 \cdot 7$ & $10 \cdot 9$ & $8 \cdot 7$ & $8 \cdot 0$ & $9 \cdot 2$ & $8 \cdot 1$ & $9 \cdot 0$ & $8 \cdot 8$ \\
\hline $\mathrm{C}_{36: 2}$ & $6 \cdot 4$ & $4 \cdot 3$ & $5 \cdot 3$ & $12 \cdot 0$ & $8 \cdot 4$ & $10 \cdot 1$ & $10 \cdot 7$ & $8 \cdot 6$ & $6 \cdot 5$ \\
\hline $\mathrm{C}_{36: 1}$ & $3 \cdot 2$ & $2 \cdot 9$ & $3 \cdot 3$ & $5 \cdot 3$ & $3 \cdot 5$ & $3 \cdot 8$ & $4 \cdot 3$ & $4 \cdot 5$ & $2 \cdot 7$ \\
\hline$\%$ UM to $\mathrm{TM}^{*}$ & $39 \cdot 7$ & $37 \cdot 4$ & $40 \cdot 1$ & $57 \cdot 6$ & $50 \cdot 0$ & $52 \cdot 9$ & $53 \cdot 2$ & $49 \cdot 8$ & $44 \cdot 4$ \\
\hline $\begin{array}{l}\text { Relative } \% \text { of } \\
\text { total } \dagger\end{array}$ & $2 \cdot 0$ & $16 \cdot 1$ & 4.9 & 4.9 & $31 \cdot 0$ & $7 \cdot 7$ & $5 \cdot 2$ & $7 \cdot 5$ & $4 \cdot 8$ \\
\hline
\end{tabular}

* See Table 4.

† See Table 5.

at all stages of growth and the amount of mycolic acids in culture fluids increased during growth $(7.9 \%$ and $6.5 \%$ for MLB133 and MLB194, respectively, in the final samples). Relative to the parent strain grown under similar conditions in LBG, strain MLB133 always showed a lower proportion of $\mathrm{C}_{32: 0}$ and a higher relative proportion of $\mathrm{C}_{36: 2}$, and MLB194 normally showed a lower proportion of $\mathrm{C}_{32: 0}$ and a higher proportion of $\mathrm{C}_{34: 1}$ (see analyses for LBG, Tables 4-7). These results further indicated that mycolic acid synthesis in mutants MLB133 and MLB194 had been altered in a way which resulted in changes in the proportion of unsaturated mycolic acids and further showed that a higher proportion of mycolic acids were found extracellularly during growth, an observation consistent with detecting a lower proportion of covalently bound mycolic acids following defatting.

\section{Effect of growth in the presence of glycine or INH on mycolic acid composition}

Previously observed changes in morphology, protoplasting ability and efficiency of transformation of AS019 following growth in the presence of glycine and INH could be explained by modulation of cell-surface components. To evaluate any changes in mycolic acid synthesis in AS019 and mutants MLB133 and MLB194, strains were grown in shake-flask culture in LBG and LBG containing $2 \%(\mathrm{w} / \mathrm{v})$ glycine or $4 \mathrm{mg} \mathrm{INH} \mathrm{ml}^{-1}$, harvesting cells in early stationary phase. Analysis of mycolic acids in whole cells and culture fluids was performed without TLC purification of MAMEs, to minimize losses during the extraction procedures (Table 6). The proportion of each mycolic acid type produced by AS019 and the mutants in the control cultures (LBG) demonstrated the same relativities as seen above, with $\mathrm{C}_{32: 0}$ the dominant mycolic acid in AS019 $(51.0 \%)$ and relatively lower proportions of this in MLB133 (34\%) and MLB194 $(39 \%)$. Again, the latter strains showed proportionately higher levels of $\mathrm{C}_{34: 1}$ and $\mathrm{C}_{36: 2}$ and higher proportions of unsaturated mycolic acids in toto. Growth in the presence of glycine and INH had little impact on the relative proportions of mycolic acids detected in ASO19, with the notable exception that $16.1 \%$ of the total mycolic acids were found extracellularly after growth with glycine. Similar increases in extracellular mycolic acids were seen for strain MLB133 after growth with glycine, with $31 \%$ of the total mycolic acids found in the culture fluids, but strain MLB194 was not as dramatically affected. Other changes in the relative proportions of mycolic acids for the mutants grown in glycine or INH media were not prominent.

Although the presence of glycine plus INH had been shown to improve electrotransformation frequencies in AS019, growth in INH alone had little impact except at very high concentrations $\left(>5 \mathrm{mg} \mathrm{ml}^{-1}\right.$ ) (Haynes \& Britz, 1990), data which are consistent with the above observations that growth with $4 \mathrm{mg} \mathrm{INH} \mathrm{ml}^{-1}$ had little impact on the type or position of mycolic acids in AS019. To determine whether higher concentrations of INH had any impact on mycolic acid synthesis, AS019 and the mutants were grown in LBG supplemented with $8 \mathrm{mg} \mathrm{INH} \mathrm{ml}^{-1}$, harvesting at late stationary phase and analysing mycolic acids in whole cells and culture fluids 
Table 7. Relative proportion of mycolic acids in culture fluids of $C$. glutamicum strains after growth with $8 \mathrm{mg} \mathrm{INH} \mathrm{ml}^{-1}$

Cultures containing $100 \mathrm{ml}$ medium were grown in $250 \mathrm{ml}$ flasks at $30^{\circ} \mathrm{C}$, and harvested at late stationary growth phase $\left(\mathrm{OD}_{600} 4-5\right)$. Mycolic acids were extracted from dried whole cells and culture fluids as described in Methods, omitting TLC purification. After acid methanolysis of the dried samples, samples were extracted using petroleum ether, dried under $\mathrm{N}_{2}$, silylated to TMS ethers and then analysed by GC. LBG-I, LBG supplemented with $8 \mathrm{mg} \mathrm{INH} \mathrm{ml}^{-1}$. The results represent the proportion ( $\%$ ) of each mycolic acid found in whole cells.

\begin{tabular}{|c|c|c|c|c|c|c|}
\hline \multirow[t]{2}{*}{ Mycolic acid } & \multicolumn{2}{|c|}{ AS019 } & \multicolumn{2}{|c|}{ MLB133 } & \multicolumn{2}{|c|}{ MLB194 } \\
\hline & LBG & LBG-I & LBG & LBG-I & LBG & LBG-I \\
\hline $\mathrm{C}_{32: 0}$ & $58 \cdot 2$ & $48 \cdot 8$ & $52 \cdot 7$ & $38 \cdot 7$ & $52 \cdot 2$ & $39 \cdot 1$ \\
\hline $\mathrm{C}_{34: 1}$ & $28 \cdot 4$ & $35 \cdot 8$ & $32 \cdot 6$ & $41 \cdot 0$ & $32 \cdot 4$ & $40 \cdot 4$ \\
\hline $\mathrm{C}_{34: 0}$ & $7 \cdot 2$ & $5 \cdot 3$ & 6.4 & $5 \cdot 3$ & $7 \cdot 7$ & $5 \cdot 3$ \\
\hline $\mathrm{C}_{36: 2}$ & $4 \cdot 2$ & $8 \cdot 0$ & $6 \cdot 1$ & $12 \cdot 3$ & $5 \cdot 5$ & $12 \cdot 0$ \\
\hline $\mathrm{C}_{36: 1}$ & 1.9 & $2 \cdot 1$ & $2 \cdot 3$ & $2 \cdot 8$ & $2 \cdot 3$ & $3 \cdot 2$ \\
\hline$\%$ UM to $\mathrm{TM}^{*}$ & $34 \cdot 5$ & $45 \cdot 9$ & $41 \cdot 0$ & $56 \cdot 1$ & $40 \cdot 2$ & $55 \cdot 6$ \\
\hline Relative $\%$ of total $\dagger$ & $5 \cdot 9$ & $8 \cdot 5$ & $9 \cdot 2$ & $18 \cdot 8$ & $10 \cdot 3$ & $21 \cdot 2$ \\
\hline
\end{tabular}

* See Table 4.

† See Table 5 .

(Table 7). Following growth of AS019 with $8 \mathrm{mg}$ INH $\mathrm{ml}^{-1}$, the relative proportion of $\mathrm{C}_{32: 0}$ was decreased, $\mathrm{C}_{34: 1}$ and $\mathrm{C}_{36: 2}$ increased, and the total unsaturated mycolic acids and extracellular mycolic acids were increased relative to the control cultured in parallel. Similar trends were also seen for mutants MLB133 and MLB194, where 18.8 and $21 \cdot 2 \%$ of mycolic acids, respectively, were extracellular in INH broths. The cumulative effects of glycine plus INH were not evaluated in this study.

\section{DISCUSSION}

The majority of previous studies on mycolic acid structures in the nocardioform group of bacteria have concentrated on identifying the types and proportions of these cell-surface components in the context of taxonomic differentiation of species. Collins et al. (1982a, b) reported the qualitative analysis of mycolic acids from late-stationary phase cells of saprophytic, glutamicacid-producing coryneform species, which showed that C. glutamicum NCIB 10025 and Brevibacterium lactofermentum made $\mathrm{C}_{32}-\mathrm{C}_{36}$ mycolic acids whereas $\mathrm{C}_{28}-$ $\mathrm{C}_{36}$ mycolic acids were made by $B$. flavum. These saprophytes were distinctive from pathogenic corynebacteria, which produced different suites of mycolic acids: C. ulcerans synthesizes mycolic acids with exceptionally low carbon numbers $\left(\mathrm{C}_{20}-\mathrm{C}_{32}\right)$ (Yano \& Saito, 1972), C. diphtheriae makes $\mathrm{C}_{20}-\mathrm{C}_{35}$ (Corina \& Sesardic, 1980) and C. urealyticum exhibits $C_{26}-C_{30}$ mycolic acids (Herrera-Alcaraz et al., 1993). In the present study, it was shown that C. glutamicum ATCC 13059 makes $\mathrm{C}_{32}-\mathrm{C}_{36}$ mycolic acids and that two components $\left(\mathrm{C}_{32: 0}, \mathrm{C}_{34: 1}\right)$ are the dominant types synthesized, confirming previous results of Collins et al. (1982a) for this species. Although it had been anticipated that mycolic acid composition may change during growth, a concept based on the observation that cells harvested earlier in the growth cycle were transformed more efficiently by electroporation (Haynes \& Britz, 1990), in fact the relative proportion of mycolic acids, and fatty acids, remained constant throughout the growth cycle for both cell-associated and extracellular mycolic acids produced by ATCC 13059 , where the latter showed a small increase only very late in stationary phase. Similar observations were reported by Butler et al. (1986) for pathogenic species of corynebacteria, where the age of the culture did not affect the mycolic acid patterns detected by HPLC analysis. However, the mutant strains, MLB133 and MLB194, did show changes in the relative proportions of mycolic acids synthesized as growth progressed, where increased relative production of unsaturated mycolic acids occurred for both strains and this paralleled increased relative production of saturated fatty acids $\left(\mathrm{C}_{16: 0}\right.$ and $\left.\mathrm{C}_{18: 0}\right)$ at the expense of $\mathrm{C}_{18: 1}$ in MLB133. Furthermore, the proportion of mycolic acids which were either extractable from cells (non-covalently bound) or found in the culture fluids was higher for the mutants. Analysis of extracellular mycolic acids in vitro by nocardioform bacteria is rarely mentioned in the literature, with the notable exception of production of surfactants by C. hydrocarboclastum (Zajic et al., 1977), so that it is difficult to compare this phenomenon across species. However, the changes in mycolic and fatty acid profiles, plus increased extracellular production of the former by these presumptive cell-surface mutants, distinguished these strains at least from their parent and was consistent with their observed relative ease of protoplasting (Best \& Britz, 1986) and transformation (K.-H. Jang, unpublished observation). 
Our earlier work reported the isolation of a family of isoleucine auxotrophs which were morphologically distinct from the parent strain of C. glutamicum, ATCC 13059 , and which protoplasted more readily following growth in media supplemented with set concentrations of glycine and INH, and lysozyme treatment (Best $\&$ Britz, 1986). The scanning electron micrographs presented here confirm the pleomorphism observed originally for these mutants using light microscopy, where the progenitor strains of MLB133 and MLB194 showed greater budding and branching following growth in glycine, morphology which is more characteristic of other nocardioform species. Furthermore, it was shown that mutants MLB133 and MLB194 exhibited hypersensitivity towards glycine and INH relative to the parent strain, which was manifested by slower specific growth rates and greater morphological changes when cultured with $2 \%$ glycine or $4 \mathrm{mg} \mathrm{INH} \mathrm{ml}^{-1}$. When used at $2 \%$, glycine had little impact on the cellular mycolic acid profiles of AS019, MLB133 and MLB194 except for a possible small decline in the relative levels of unsaturated mycolic acids. This is not surprising, considering that the presumptive target for glycine action in C. glutamicum and other Gram-positive bacteria is the peptidoglycan (Hammes et al., 1973). However, the most obvious impact of including glycine was a large increase in the extracellular mycolic acids for strains AS019 and MLB133, suggesting that glycine impacts either directly or indirectly upon the attachment of corynemycolic acids to the cell surface. Although the cell-surface architecture of C. glutamicum has not been studied in detail, from work in related species and mycobacteria it is likely that corynemycolic acids link covalently to arabinose units of the arabinogalactan, which in turn links to the peptidoglycan via a phosphodiester bridge (Nikaido et al., 1993; Brennan \& Nikaido, 1995). Destabilization of peptidoglycan cross-linking by glycine incorporation could impair arabinogalactan linking to the altered backbone, leading to a looser external structure which resulted in 'leakage' of mycolic acidarabinogalactan structures into the culture fluids. Detecting the presence of such structures in culture filtrates of AS019 or the mutants remains experimentally untested and acid methanolysis used in preparing MAMEs for analysis in the present work would have disrupted the covalent bonds. Alternatively, glycine may interfere directly with translocation of corynemycolic acids from presumptive, as yet unidentified, carriers via transacylation to arabinose units in the arabinogalactan. The latter reactions are the least studied part of the mycobacterial mycolic acid biosynthetic pathway (Brennan \& Nikaido, 1995) and similar reactions in C. glutamicum have not been reported. However, because the above observations suggest that glycine acts on sites other than peptidoglycan cross-linking, further experimental investigation of its site of action in C. glutamicum is warranted.

Models for synthesis of mycolic acids in mycobacteria and related species propose that cellular fatty acids undergo chain elongation and modification (carboxy- lation, introduction of carrier groups, desaturation) to produce the two forms of mycolates which are either bound to arabinogalactan or occur as trehalose dimycolates (Brennan \& Nikaido, 1995). Evidence for involvement of fatty acids as precursors for corynemycolic acids includes the incorporation of $\left[1{ }^{14} \mathrm{C}\right]$ palmitate into $\mathrm{C}_{32}$ mycolates of $\mathrm{C}$. diphtheriae (Gastambide-Odier \& Lederer, 1959; Walker et al., 1973) and $\left[1-{ }^{14} \mathrm{C}\right]$ stearic acid into $\mathrm{C}_{34: 0} / \mathrm{C}_{34: 1}$ and $\mathrm{C}_{36: 0} / \mathrm{C}_{36: 1}$ in Bacterionema (now Corynebacterium) matruchotti (Shimakata et al., 1984). INH inhibits mycolic acid synthesis in mycobacteria (Quémard et al., 1995; Winder \& Collins, 1970) and nocardioform species (Tomiyasu \& Yano, 1984). Tomiyasu \& Yano (1984) reported that when $50 \mu \mathrm{g}$ INH $\mathrm{ml}^{-1}$ was present in growth medium of Nocardia rubra, $N$. lutea and one strain of Rhodococcus rhodochrous, the amount of mycolic acids and possible intermediates, very long-chain non-polar fatty acids, decreased and synthesis of longer-chained mycolic acids $\left(>\mathrm{C}_{44}-\mathrm{C}_{46}\right)$ was specifically inhibited. The latter occurred through specific inhibition of chain elongation or desaturation of precursor long-chain fatty acids $\left(\mathrm{C}_{28}\right.$ or $\left.\mathrm{C}_{30}\right)$. In contrast, neither changes in the structure of mycolic acids nor growth inhibition were observed in the pathogenic corynebacterium C. xerosis, which synthesizes $\mathrm{C}_{26}$ to $\mathrm{C}_{36}$ mycolates, or another strain of $R$. rhodochrous. Based on these observations, these authors suggested that INH inhibited synthesis of mycolic acids longer than $\mathrm{C}_{44}$ or $\mathrm{C}_{46}$ specifically. However, the concentration of INH tested may not have been high enough to elicit an effect in C. xerosis of the second strain of $R$. rhodochrous, bearing in mind that our work showed that only concentrations between 4 and $8 \mathrm{mg} \mathrm{ml}^{-1}$ had any significant impact on mycolic acid pattern in C. glutamicum.

Recently, the target site of INH in M. tuberculosis and several other mycobacterial species was identified as the InhA protein, which is a 2-trans-enoyl-acyl carrier protein involved in fatty acid synthesis (Dessen et al., 1995): the product of the inhA gene has more than $40 \%$ sequence identity over 203 amino acids with the EnvM proteins of E. coli and Salmonella typhimurium, and EnvM is thought to participate in fatty acid biosynthesis in these species (Bergler et al., 1992; Turnowsky et al., 1989). Although C. glutamicum is relatively insensitive to $\mathrm{INH}$, when this compound was included in growth media at high concentrations $\left(8 \mathrm{mg} \mathrm{m}^{-1}\right)$, all of the $C$. glutamicum strains tested had decreased relative proportions of $\mathrm{C}_{32: 0}$ and $\mathrm{C}_{34: 0}$ with parallel increased proportions of $\mathrm{C}_{34: 1}$ and $\mathrm{C}_{36: 2}$, and extracellular mycolates increased to $18-21 \%$ for the mutants. These results suggested that INH inhibited synthesis of shorterchained, saturated mycolic acids in all strains and also further impaired covalent binding of mycolates to the cell surface in the mutants. Although fatty acid analysis was not performed following growth of the mutant strains in INH, when strain MLB133 was cultured in the basal medium, stearic acid was accumulated late in growth and there appeared to be a small increase in the amount of palmitic acid also. One explanation for the 
observed hypersensitivity to INH in this strain may be that elongation of $\mathrm{C}_{16}$ and $\mathrm{C}_{18}$ fatty acids to their counterpart corynemycolates is impaired, giving rise to decreased synthesis of $\mathrm{C}_{32: 0}$ and accumulation of these fatty acids during growth. How this would affect the extracellular distribution of mycolates remains subject to speculation. We are currently pursuing further information on the biochemistry of mycolic acid synthesis in C. glutamicum and the properties of the inhA gene equivalent in this species to provide sufficient background to understand the nature of the genetic changes in these mutants and to provide some insight into mycolic acid synthesis in this species.

\section{ACKNOWLEDGEMENTS}

We would like to thank Nikola Popovik (research assistant) and Albert Juhasz ( $\mathrm{PhD}$ student) for their advice on technical procedures. Ki-Hyo Jang was supported on a PhD scholarship provided by the Targeted Institutional Links Program, Department of Employment, Education and Training, Australia.

\section{REFERENCES}

Athalye, M., Noble, W. C., Mallet, A. I. \& Minnikin, D. E. (1984). Gas chromatography-mass spectrometry of mycolic acids as a tool in the identification of medically important coryneform bacteria. J Gen Microbiol 130, 513-519.

Banerjee, A., Dubnau, E., Quémard, A., Balasubramanian, V., Um, K. S., Wilson, T., Collins, D., de Lisle, G. \& Jacobs, W. R., Jr. (1994). inbA, a gene encoding a target for isoniazid and ethionamide in Mycobacterium tuberculosis. Science 263, 227-230.

Barksdale, L. \& Kim, K. S. (1977). Mycobacterium. Bacteriol Rev 41, 217-372.

Bergler, H., Hogenauer, G. \& Turnowsky, F. (1992). Sequences of the envM gene and of two mutated alleles in Escherichia coli. $J$ Gen Microbiol 138, 2093-2100.

Best, G. R. \& Britz, M. L. (1986). Facilitated protoplasting in certain auxotrophic mutants of Corynebacterium glutamicum. Appl Microbiol Biotechnol 23, 288-293.

Billman-Jacobe, H., Wang, L., Kortt, A., Stewart, D. \& Radford, A. (1995). Expression and secretion of heterologous protease by Corynebacterium glutamicum. Appl Environ Microbiol 61, 1610-1613.

Bligh, E. G. \& Dyer, W. J. (1959). A rapid method for total lipid extraction and purification. Can J Biochem Physiol 37, 911-917.

Brennan, P. J. \& Nikaido, H. (1995). The envelope of mycobacteria. Annu Rev Biochem 64, 29-63.

Butler, W. R., Ahearn, D. G. \& Kilburn, J. O. (1986). Highperformance liquid chromatography of mycolic acids as a tool in the identification of Corynebacterium, Nocardia, Rhodococcus, and Mycobacterium species. J Clin Microbiol 23, 182-185.

Chevalier, J., Pommier, M.-T., Cremieux, A. \& Michel, G. (1988). Influence of Tween 80 on the mycolic acid composition of three cutaneous corynebacteria. J Gen Microbiol 134, 2457-2461.

Collins, M. D., Goodfellow, M. \& Minnikin, D. E. (1982a). A survey of the structures of mycolic acids in Corynebacterium related taxa. J Gen Microbiol 128, 129-149.

Collins, M. D., Goodfellow, M. \& Minnikin, D. E. (1982b). Fatty acid composition of some mycolic acid-containing coryneform bacteria. J Gen Microbiol 128, 2503-2509.

Corina, D. L. \& Sesardic, D. (1980). Profile analysis of total mycolic acids from skin corynebacteria and from named Corynebacterium strains by gas-liquid chromatography and gas-liquid chromatography/mass spectrometry. J Gen Microbiol 116, 61-68.

Dessen, A., Quémard, A., Blanchard, J. S., Jacobs, W. R., Jr \& Sacchettini, J. C. (1995). Crystal structure and function of the isoniazid target of Mycobacterium tuberculosis. Science 267, 1638-1641.

Gastambide-Odier, M. \& Lederer, E. (1959). Biosynthesis of corynemycolic acid from two molecules of palmitic acid. Nature 184, 1563-1564.

Hammes, W., Schleifer, K. H. \& Kandler, O. (1973). Mode of action of glycine on the biosynthesis of peptidoglycan. J Bacteriol 116, 1029-1053.

Haynes, J. A. \& Britz, M. L. (1990). The effect of growth conditions of Corynebacterium glutamicum on the transformation frequency obtained by electroporation. J Gen Microbiol 136, 255-263.

Herrera-Alcaraz, E., Valero-Guillen, P., Martín-Luengo, F. \& Canteras-Jordana, M. (1993). Numerical analysis of fatty and mycolic acid profiles of Corynebacterium urealyticum and other related corynebacteria. Microbiologia 9, 53-62.

Hopwood, D. A., Wright, H. M., Bibb, M. J. \& Cohen, S. N. (1977). Genetic recombination through protoplast fusion in Streptomyces. Nature 268, 171-174.

Jang, K. H., Chambers, P. J. \& Britz, M. L. (1996). Analysis of nucleotide methylation in DNA from Corynebacterium glutamicum and related species. FEMS Microbiol Lett 136, 309-315.

Jarlier, V. \& Nikaido, H. (1990). Permeability barrier to hydrophilic solutes in Mycobacterium cheloni. J Bacteriol 172, 1418-1423.

Jarlier, V. \& Nikaido, H. (1994). Mycobacterial cell wall : structure and role in natural resistance to antibiotics. FEMS Microbiol Lett 123, 11-18.

Katsumata, R., Ozaki, A., Oka, T. \& Furuya, A. (1984). Protoplast transformation of glutamate-producing bacteria with plasmid DNA. J Bacteriol 159, 306-311.

Liebl, W., Sinskey, A. J. \& Schleifer, K. H. (1992). Expression, secretion, and processing of staphylococcal nuclease by Corynebacterium glutamicum. J Bacteriol 174, 1854-1861.

Minnikin, D. E., Patel, P. V., Alshamaony, L. \& Goodfellow, M. (1977). Polar lipid composition in the classification of Nocardia and related bacteria. Int J Syst Bacteriol 27, 104-117.

Minnikin, D. E., Hutchinson, I. G., Caldicott, A. B. \& Goodfellow, M. (1980). Thin layer chromatography of methanolysates of mycolic acid-containing bacteria. J Chromatogr 188, 221-233.

Nikaido, H., Kim, S. H. \& Rosenberg, E. Y. (1993). Physical organization of lipids in the cell wall of Mycobacterium chelonae. Mol Microbiol 8, 1025-1030.

Quémard, A., Mazeres, S., Sut, A., Lanéelle, G. \& Lacave, C. (1995). Certain properties of isoniazid inhibition of mycolic acid synthesis in cell-free systems of Mycobacterium aurum and $M$. avium. Biochim Biophys Acta 1254, 98-104.

Schafer, A., Schwarzer, A., Kalinowski, J. \& Puhler, A. (1994). Cloning and characterization of a DNA region encoding a stresssensitive restriction system from Corynebactrium glutamicum ATCC 13032 and analysis of its role in intergeneric conjugation with Escherichia coli. J Bacteriol 176, 7309-7319.

Serwold-Davis, T. M., Groman, N. \& Rabin, M. (1987). Transformation of Corynebacterium diphtheriae, Corynebacterium ulcerans, Corynebacterium glutamicum, and Escherichia coli with the C. diphtheriae plasmid pNG2. Proc Natl Acad Sci USA 84, $4964-4968$.

Shimakata, T., Iwaki, M. \& Kusaka, T. (1984). In vitro synthesis of 
mycolic acids by the fluffy layer fraction of Bacterionema matruchotii. Arch Biochem Biophys 229, 329-339.

Smith, M. D., Flickinger, J. L., Lineberger, D. W. \& Schmidt, B. (1986). Protoplast transformation in coryneform bacteria and introduction of an $\alpha$-amylase gene from Bacillus amyloliquefaciens into Brevibacterium lactofermentum. Appl Environ Microbiol 51, 634-639.

Tauch, A., Kirchner, O., Wehmeier, L., Kalinowski, J. \& Puhler, A. (1994). Corynebacterium glutamicum DNA is subjected to methylation-restriction in Escherichia coli. FEMS Microbiol Lett 123, 343-348.

Tomiyasu, I. (1982). Mycolic acid composition and thermally adaptative changes in Nocardia asteroides. J Bacteriol 151, 828-837.

Tomiyasu, I. \& Yano, I. (1984). Isonicotinic acid hydrazide induced changes and inhibition in mycolic acid synthesis in Nocardia and related taxa. Arch Microbiol 137, 316-323.

Turnowsky, F., Fuchs, K., Jeschek, C. \& Högenauer, G. (1989). envM genes of Salmonella typhimurium and Escherichia coli. $J$ Bacteriol 171, 6555-6565.

Walker, R. W., Promé, J.-C. \& Lacave, C. (1973). Biosynthesis of mycolic acids : formation of $\mathrm{a} \mathrm{C}_{32} \beta$-keto ester from palmitic acid in a cell-free system of Corynebacterium diphtheriae. Biochim Biophys Acta 326, 52-62.

Winder, F. G. \& Collins, P. B. (1970). Inhibition by isoniazid of synthesis of mycolic acids in Mycobacterium tuberculosis. J Gen Microbiol 63, 41-48.

Wolf, H., Puhler, A. \& Neumann, E. (1989). Electrotransformation of intact and osmotically sensitive cells of Corynebacterium glutamicum. Appl Microbiol Biotechnol 30, 283-289.

Yano, I. \& Saito, K. (1972). Gas chromatography and mass spectrometric analysis of molecular species of corynemycolic acids from Corynebacterium ulcerans. FEBS Lett 23, 352-356.

Yoshihama, M., Higarshiro, K., Rao, E. A., Akedo, M., Shanabruch, W. G., Follettie, M. T., Walker, G. C. \& Sinskey, A. J. (1985). Cloning vector system for Corynebacterium glutamicum. $J$ Bacteriol 162, 591-597.

Zajic, J. E., Guigward, H. \& Gerson, D. F. (1977). Emulsifying and surface active agents from Corynebacterium hydrocarboclastum. Biotechnol Bioeng 19, 1295-1301.

Received 14 February 1997; revised 9 June 1997; accepted 10 June 1997. 